\title{
Serum progesterone as an indicator of cyclic activity in post-partum goat does
}

\author{
V.M. Mmbengwa ${ }^{1 \#}$, B.M. Gundidza ${ }^{2}$, J.P.C. Greyling ${ }^{3}$, M.D. Fair ${ }^{3}$, L.M.J. Schwalbach ${ }^{3}$, \\ J.E.J. du Toit ${ }^{3}$ and A. Samie \\ ${ }^{1}$ Department of Animal Production and Management, Nelson Mandela Metropolitan University (NMMU), \\ George Campus, South Africa \\ ${ }^{2}$ Department of Pharmacy \& Pharmacology, Faculty of Health Science, University of Witwatersrand, \\ 7 York Road, Parktown, Johannesburg, South Africa \\ ${ }^{3}$ Department of Animal, Wildlife \& Grassland Science, University of Free State, Bloemfontein 9300, South Africa \\ ${ }^{4}$ Department of Microbiology, University of Venda, Thohoyandou, South Africa
}

\begin{abstract}
The aim of this trial was to assess post-partum ovarian activity of the does of two South African goat breeds from their serum progesterone concentrations. Between seven and 100 days post-partum, does from the Boer goat breed and an indigenous rural goat type were allocated to two nutritional treatments within breed. One group per breed received a concentrated diet in an intensive feeding programme. The other group per breed was subjected to a low level of nutrition through the grazing of the natural pasture in an extensive (veld) grazing system. Blood samples were collected weekly from five does per breed per treatment. Serum progesterone concentrations were determined using a Gamma Coat ${ }^{\mathrm{TM}}$ [128] progesterone radioimmunoassay kit (Sorin Diagnostics, France). Large variations in serum progesterone concentrations were recorded within and between breeds and nutritional regimens. Irrespective of breed, in the extensive groups subjected to the low level of nutrition, mean peak serum progesterone concentrations never exceeded $0.2 \mathrm{ng} / \mathrm{mL}$. This suggests that throughout the experimental period, ovarian activity remained low in the extensive groups. It was concluded that nutritional regimen plays a significant role in ensuring high ovarian activities. Furthermore, the higher mean serum progesterone levels in the Boer goat indicate an earlier and higher oestrous activity, compared to the indigenous does.
\end{abstract}

Keywords: Goat, serum, ovarian activity, Boer goat, indigenous

\# Corresponding author. E-mail: vmmmbengwa@gmail.com, vfmmmbengwa@yahoo.com

\section{Introduction}

Indigenous goats are important animals in many countries because they possess genotype that makes them withstand unfavourable nutritional conditions and also they are known to be cheap in their maintenance. Consequently, these animals are predominantly kept by rural poor population for their livelihood and food security. In Africa, these animals are found in large numbers due to the aforesaid reasons and also due to their importance in traditional feasts. Zarkawi et al., (1999) reported that these animals are kept as dual purpose breeds (i.e. they are kept for both meat and milk production).

Boer (Capra hircus) and indigenous (Nguni Feral) goats are regarded as original South African meat producing goats ( $\mathrm{Lu}$, undated). In addition, this author has also reported that the Boer goat's origin unlike that of the Indigenous goat is unclear. It is believed that Boer goats have originated from the genetic pool of African Indigenous goat, Indian goats, Angora goats and some European dairy goats, whilst the Indigenous goats are probably from Namaqua Hottentots and from southward Bantu tribes ( $\mathrm{Lu}$, undated).These breeds are partially seasonal breeders. Their reproductive cycle is virtually year-round as long as the nutritional conditions are favourable. These goats cycle every 18 to 21 days. Greyling, (1990) indicated that about $17 \%$ does cycles are shorter than 13 days and 10\% cycles longer than 25 days. This means that the mean length of oestrus is $37.4 \mathrm{~h}$ and has a mean gestation period of approximately 148 days ( $\mathrm{Lu}$, undated). 
Reproduction is a major factor contributing to the efficiency of meat and milk production (Khanum et al., 2008). These authors contend that many genetic, environmental and physiological factors affect the reproductive efficiency of the female goat. Zarkawi \& Soukouti, (2001) further suggested that an assessment of progesterone levels during different physiological stages in animals is considered one of the most important parameters to determine their fertility status. Progesterone concentrations play a pivotal role in determining reproduction efficiency (Mmbengwa, 1999). Lucy (2001) reported that low progesterone concentrations during early embryonic development may cause pregnancy failure and thereby decreasing productivity. Increasing peripheral progesterone concentrations at an early stage (day 5) and late stage (day 15) of the oestrous cycle may help reduce embryonic deaths (Cavalieri, 2005; Howard et al., 2006). The Boer goat breed has a reputation of having a high fertility, with conception rates averaging $98 \%$ for does bred under good management and nutritional conditions (Campbell, 1984). Van der Nest (1997) indicated reproduction efficiency to be one of the main factors determining the overall productivity. This determines the number of excess stock for sale and the meat and milk available for human consumption. The aim of this investigation was to assess the ovarian activity of two South African goat breeds subjected to different levels of nutrition, by measuring the serum progesterone concentration of the does during the post-partum period.

\section{Materials and Methods}

This research was carried out on two experimental farms; each farm had both Boer and Indigenous goat groups. The goats kept inside the house were regarded as the intensive group, whilst the one kept in camps on the farm were referred to as extensive group. The intensive groups were kept at the small stock building at the University of Free State campus; this building is located at the north west side of the Faculty of Agriculture main building. This location is 1412 meters above sea level. An extensive group of animals were kept at Paradys experimental farm located at the south eastern side of Bloemfontein city centre. This experimental farm is situated approximately $20 \mathrm{~km}$ from Bloemfontein. It is situated at a latitude of 28.34 south, longitude of 25.89 east and an altitude of $1412 \mathrm{~m}$ above sea level. This study was carried out during the winter season with low quality or poor nutrition.

Two goat breeds and two nutritional management systems were used in this trial. Thirty six (36) recently kidded does (18 Boer goats and 18 indigenous rural goats) were available for the research. The investigation was conducted between seven (7) and hundred (100) days post-partum interval. Half $(n=9)$ the Boer goat does and half $(\mathrm{n}=9)$ the indigenous does were allocated randomly within breed to an extensive (veld) feeding treatment, and the other half per breed to an intensive (high energy) feeding treatment (Table 1).

Table 1 Nutritional composition of pelleted lamb-ram-ewe diet (Senwesco Feeds Ltd)

\begin{tabular}{lcc}
\hline Total Protein & 130 & $(34.92 \%)$ \\
Urea & - & 10 \\
\% of total protein derived from Urea & - & 120 \\
Moisture & - & 150 \\
Fibre & 25 & - \\
Fat & 10 & 10 \\
NH ${ }_{4}$ & 10 & 15 \\
Calcium & 3 & - \\
Phosphorus & & \\
\hline
\end{tabular}

The goats does were adapted to the diet for two weeks prior to the trial period. During the experimental period, clear fresh water was always available ad libitum. These goats were fed a pelleted 
lamb-ram-ewe diet (Senwesco Feeds Ltd) in a paddock (Table 1), while the extensive treatment groups were allowed to graze freely on natural pastures. This pasture was at Paradys University experimental farm. In this farm, no supplementary feed was provided to these groups except water. This is despite the poor veld condition caused by the cold winter season (an average of $10^{\circ} \mathrm{C}$ ) and low humidity. The pastures consisted of $80 \%$ red grass (Themeda triandra), 15\% of a species of finger grass (Digitaria eriantha) and weeping love grass (Eragrostis species) and 5\% of other minor species. In this group, feed intake could not be measured. Water was freely available to all the animals.

Blood samples $(10 \mathrm{~mL})$ were collected weekly from five $(\mathrm{n}=5)$ different animals per breed per feeding system. These samples were taken by jugular vein puncture using vacutainers and needles. The serum was recovered by centrifuging the blood for $15 \mathrm{~min}$ at 2500 r.p.m. Serum was aspirated and stored at $-18{ }^{\circ} \mathrm{C}$ until the assay for serum progesterone concentration could be performed. Progesterone concentration was determined using a Gamma Coat ${ }^{\mathrm{TM}}$ [128] progesterone radioimmunoassay kit (Sorin Diagnostics, France). The mean serum progesterone levels were analysed using the one-way ANOVA with treatments in a $2 \times 2$ factorial design. This data analysis was carried out using the General Linear Models Procedures of SAS (1991).

\section{Results and Discussion}

The determination of serum progesterone concentrations in the post-partum goats revealed the mean progesterone concentration to vary according to breed and nutritional environment. Table 2 and Figure 1 clearly indicated that the serum progesterone concentration of the Boer goat does (intensive group) was higher than that of all the other treatment groups during the early lactation (Week 3) and mid-lactation post-partum (Week 7) periods. The serum progesterone concentration for the Boer goat does that were intensively fed, increased after peak lactation, which was found to be an indication of sexual activity due to corpus luteum or ovarian activity (progesterone secretion). It was also found that the serum progesterone concentrations for this group declined with a decrease in feed intake. These results are in agreement with the studies done by Barnicoat et al. (1949), Peart $(1967 ; 1968)$ and Green et al. (2005) who found similar results during lactation.

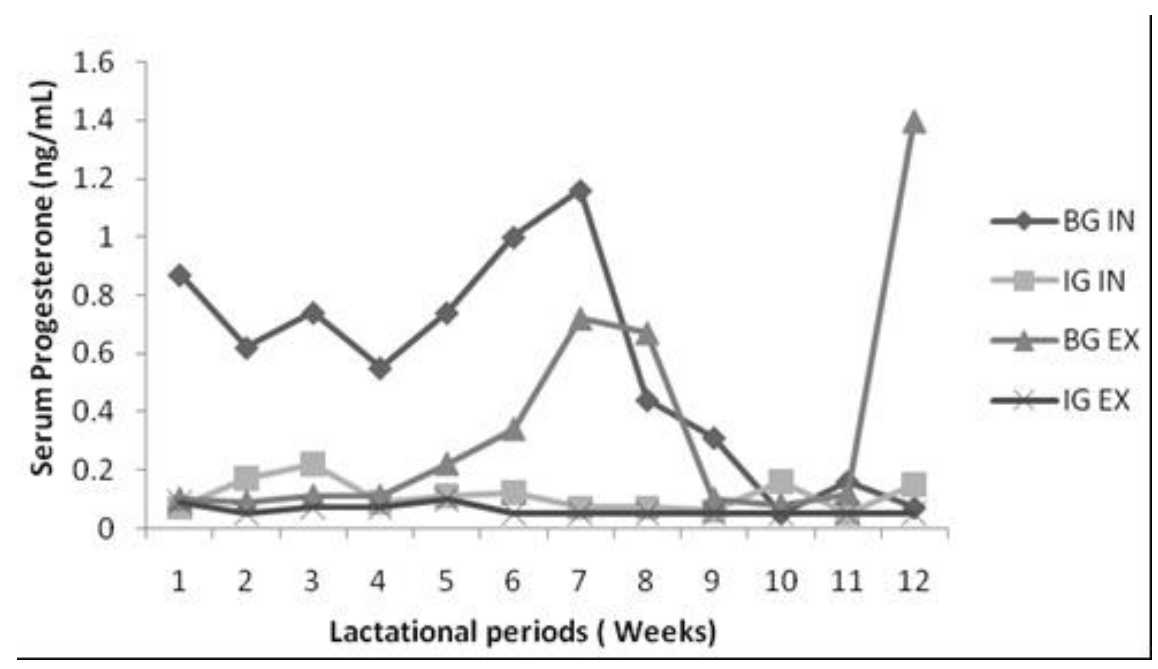

Key:

BG IN = Boer goats in an intensive feeding regimen

BG EX = Boer goats in an extensive feeding regimen

IG IN = Indigenous goats in an intensive feeding regimen

IG EX = Indigenous goats in an extensive feeding regimen.

Figure 1 Measurement of serum progesterone concentrations for Boer goat and Indigenous goat does under different intensive and extensive feeding regimens. 
Table 2 Mean ( \pm S.D.) serum progesterone level $(\mathrm{ng} / \mathrm{mL})$ for Boer and Indigenous goats does managed under different nutritional regimens

\begin{tabular}{|c|c|c|c|c|}
\hline & Boer goat & Indigenous goat & Boer goat & Indigenous goat \\
\hline 1 & $0.87 \pm 2.36$ & $0.10 \pm 0.11$ & $0.07 \pm 0.06$ & $0.09 \pm 0.11$ \\
\hline 2 & $0.62 \pm 1.51$ & $0.09 \pm 0.08$ & $0.17 \pm 0.17$ & $0.05 \pm 1.09$ \\
\hline 3 & $0.74 \pm 2.00$ & $0.11 \pm 0.08$ & $0.22 \pm 0.43$ & $0.07 \pm 0.06$ \\
\hline 4 & $0.55 \pm 1.34$ & $0.11 \pm 0.14$ & $0.09 \pm 0.10$ & $0.07 \pm 0.06$ \\
\hline 5 & $0.74 \pm 1.75$ & $0.22 \pm 0.48$ & $0.11 \pm 0.15$ & $0.10 \pm 0.09$ \\
\hline 6 & $1.00 \pm 1.88$ & $0.34 \pm 0.78$ & $0.12 \pm 0.15$ & $0.05 \pm 0.01$ \\
\hline 7 & $1.16 \pm 2.99$ & $0.72 \pm 2.03$ & $0.07 \pm 0.07$ & $0.05 \pm 1.09$ \\
\hline 8 & $0.44 \pm 1.10$ & $0.67 \pm 1.79$ & $0.07 \pm 0.08$ & $0.05 \pm 1.09$ \\
\hline 9 & $0.31 \pm 0.69$ & $0.10 \pm 0.09$ & $0.06 \pm 0.04$ & $0.05 \pm 1.09$ \\
\hline 10 & $0.05 \pm 1.08$ & $0.08 \pm 0.06$ & $0.16 \pm 0.28$ & $0.05 \pm 1.09$ \\
\hline 11 & $0.16 \pm 0.31$ & $0.12 \pm 0.14$ & $0.05 \pm 0.02$ & $0.05 \pm 1.09$ \\
\hline 12 & $0.07 \pm 0.04$ & $1.40 \pm 4.04$ & $0.15 \pm 0.29$ & $0.05 \pm 1.09$ \\
\hline
\end{tabular}

"Values in these columns differ significantly $(\mathrm{P}<0.05)$.

It can be stated that ovarian activity of the Boer goat does (intensive fed group) was suppressed by high milk production until two weeks after peak lactation (Table 3). All the breeds in the extensive environment, where energy intake was limited, exhibited low levels of serum progesterone concentrations and consequently maintained high levels of anoestrus. The indigenous goats (intensive group) showed the most elevated serum progesterone concentration one week before the end of the observation period (Week 11). This elevation in the serum progesterone level coincided with the occurrence of minimum milk yield (Table 3). This implies that during the period when milk yield increased, more energy was partitioned for milk production than for ovarian activities (Bauman et al., 1980).

Table 3 Mean ( \pm S.D.) milk production (litre) for Boer and Indigenous goats does managed under different nutritional regimens

\begin{tabular}{ccccc}
\hline & Boer goat & Indigenous goat & Boer goat & Indigenous goat \\
\hline 1 & & & & \\
2 & $2.18 \pm 1.72$ & $1.34 \pm 0.11$ & $0.06 \pm 1.27$ & $0.52 \pm 0.12$ \\
3 & $3.04 \pm 0.51$ & $1.33 \pm 0.62$ & $0.63 \pm 1.69$ & $0.67 \pm 0.58$ \\
4 & $2.99 \pm 1.57$ & $1.38 \pm 2.49$ & $0.73 \pm 0.20$ & $0.62 \pm 0.64$ \\
5 & $3.66 \pm 1.42$ & $1.21 \pm 3.03$ & $0.67 \pm 0.35$ & $0.57 \pm 0.82$ \\
6 & $3.63 \pm 1.56$ & $1.87 \pm 7.04$ & $0.52 \pm 0.44$ & $0.42 \pm 0.29$ \\
7 & $3.15 \pm 1.26$ & $1.51 \pm 6.58$ & $0.72 \pm 0.50$ & $0.62 \pm 0.31$ \\
8 & $3.11 \pm 2.40$ & $1.55 \pm 4.87$ & $1.07 \pm 0.68$ & $0.65 \pm 0.25$ \\
9 & $3.65 \pm 1.69$ & $1.64 \pm 0.09$ & $1.15 \pm 0.68$ & $0.66 \pm 0.09$ \\
10 & $3.20 \pm 1.21$ & $1.69 \pm 7.50$ & $0.55 \pm 0.46$ & $0.84 \pm 2.01$ \\
11 & $2.77 \pm 1.54$ & $1.77 \pm 5.46$ & $1.13 \pm 0.83$ & $0.56 \pm 0.95$ \\
12 & $3.16 \pm 1.20$ & $1.12 \pm 7.12$ & $1.09 \pm 0.55$ & $0.40 \pm 0.08$ \\
& $2.47 \pm 0.97$ & $1.43 \pm 5.83$ & $0.79 \pm 0.84$ & $0.46 \pm 0.12$ \\
\hline
\end{tabular}

Values in these columns differ significantly $(\mathrm{P}<0.01)$. 
All Indigenous does regardless of their nutritional treatment had low serum progesterone levels compared to the counterpart. This might be as a result of the different genetic constitution of the two breeds. Table 4 shows that these breeds also differ significantly in terms of their live weight gains $(\mathrm{P}<0.05)$, indicating that the same feed regimen has different physiological effect on different breed production and reproductive activities. In this trial, only live weight, feed intake and serum progesterone were measured. The body conditions scores of does were extrapolated from their live weight measurements.

Table 4 Mean ( \pm S.D.) live weight $(\mathrm{kg})$ for Boer and Indigenous goat does managed under different nutritional regimens

\begin{tabular}{ccccc}
\hline & Boer goat & Indigenous goat & Boer goat & Indigenous goat \\
\hline & & & & \\
1 & $49.0 \pm 11.03$ & $34.2 \pm 5.08$ & $46.8 \pm 8.02$ & $32.3 \pm 4.36$ \\
2 & $46.4 \pm 9.17$ & $31.2 \pm 5.07$ & $43.9 \pm 9.45$ & $30.3 \pm 3.91$ \\
3 & $45.9 \pm 9.19$ & $32.2 \pm 6.06$ & $44.1 \pm 7.10$ & $30.6 \pm 3.85$ \\
4 & $45.9 \pm 8.55$ & $30.4 \pm 5.61$ & $44.0 \pm 6.57$ & $29.4 \pm 4.41$ \\
5 & $44.9 \pm 9.23$ & $30.5 \pm 6.34$ & $42.8 \pm 6.62$ & $30.5 \pm 3.90$ \\
6 & $44.3 \pm 8.51$ & $31.5 \pm 5.95$ & $42.6 \pm 6.59$ & $28.4 \pm 4.74$ \\
7 & $44.3 \pm 9.06$ & $31.9 \pm 6.80$ & $40.4 \pm 7.86$ & $26.8 \pm 4.13$ \\
8 & $43.1 \pm 8.37$ & $32.3 \pm 6.93$ & $39.1 \pm 8.46$ & $28.0 \pm 4.44$ \\
9 & $42.8 \pm 8.36$ & $33.0 \pm 6.30$ & $39.8 \pm 8.37$ & $28.2 \pm 4.88$ \\
10 & $43.5 \pm 6.65$ & $33.5 \pm 6.35$ & $38.6 \pm 7.98$ & $28.8 \pm 5.06$ \\
11 & $43.1 \pm 7.49$ & $32.7 \pm 7.18$ & $40.5 \pm 7.62$ & $27.9 \pm 4.22$ \\
12 & $43.0 \pm 6.89$ & $33.2 \pm 7.86$ & $40.4 \pm 8.10$ & $27.7 \pm 4.66$ \\
\hline
\end{tabular}

Values in these columns differ significantly $(\mathrm{P}<0.05)$.

\section{Conclusion}

For both the extensive groups the mean peak serum progesterone values recorded were less than 0.2 $\mathrm{ng} / \mathrm{mL}$. Large variations in progesterone concentration were recorded within and between breeds and nutritional regimens. The results indicated that the ovarian activity remained low in the extensive groups throughout the observation period. It could be concluded that the nutritional regimen plays a significant role in ensuring high ovarian activities and furthermore, that the higher mean serum progesterone concentrations in the Boer goat indicate an earlier and higher oestrus activity post-partum compared to the indigenous does. It is, therefore, important that the extension officers or mentors be taught about the impact of the breed and nutritional regimen on the ovarian activity and reproductive efficiency in general and the critical time for the farmers and/or rural stock owners to provide supplementary ration to their lactating does in order to ensure optimal cyclic activities.

\section{Acknowledgements}

The authors would like to thank the Department of Animal, Wildlife \& Grassland Sciences at the University of the Free State and the National Research Foundation (NRF) for supporting the project.

\section{References}

Barnicoat, C.R., Logan, A.G. \& Grant, A.I., 1949. Milk secretion studies with New Zealand Romney ewes. J. Agric. Sci., Camb. 39, 44-45.

Bauman, D.E. \& Currie, W.B., 1980. Partitioning of nutrients during pregnancy and laction: A review of mechanisms involving homeostasis and homeorhesis. J. Dairy Sci. 63, 1514-1529. 
Cavalieri, J., Hepworth, G. \& Macmillan, K.L., 2005. Ovarian follicular development in Holstein cows following synchronisation of oestrus with oestradiol benzoate and an intraviginal progesterone releasing insert for 5-9 days and duration of the oestrus cycle and concentrations of progesterone following ovulation. Anim. Reprod. Sci. 81 (3-4), 177-193.

Green, M.P., Hunter, M.G. \& Mann, G.E., 2005. Relationships between maternal hormone secretion and embryo development on day 5 of pregnancy in dairy cows. Anim. Reprod. Sci. 88 (3-4), 179-189.

Greyling, J.P.C., 1990. Sexual activity of the Boer goat. Boer Goat News 9, 51-53.

Howard, J.M., Manzo, R., Dalton, J.C., Frago, F. \& Ahmadzadeh, A., 2006. Conception rates and serum progesterone concentration in dairy cattle administered gonadotropin releasing hormone 5 days after artificial insemination. Anim. Reprod. Sci. 95, 224-233.

Khanum, S.A., Hussain, M. \& Kausar, R., 2008. Progesterone and estradiol profiles during estrous cycle and gestation in Dwarf goat (Capra Hircus). Pakistan Vet. J. 28, 1-4.

Lu, C.D., Undated. Boer Goat Production: Progress and Perspective. http//www.google.com: assessed in April 2009.

Lucy, M.C., 2001. ADSA Foundation Scholar Award, Reproduction loss in high-producing dairy cattle: where will it end? J. Dairy Sci. 84, 1277-1293.

Mmbengwa, V.M., 1999. Milk production of South African Boer and Nguni feral goats under intensive and extensive feeding regimes. MSc dissertation, University of Free State, Bloemfontein, RSA.

Peart, J.N., 1967. The effect of different levels of nutrition during late pregnancy on the subsequent milk production of Black face ewes and on the growth of their lambs. J. Agric. Sci., Camb. 68, 365-371.

Peart, J.N., 1968. Lactation studies with Black face ewes and their lambs. J. Agric. Sci., Camb. 70, 87-94.

Van der Nest, M., 1997. Accelerated breeding techniques in Boer and Indigenous goats. MSc dissertation, UFS, Bloemfontein, RSA.

SAS, 1991. Statistical Analysis System user’s guide, Ver. 6. SAS Institute Inc., Cary, N.C., USA.

Zarkawi, M. \& Soukouti, 2001. Serum progesterone level using radioimmunoassay during oestrus cycle of indigenous Damascus does. N. Z. J. Agric. Res. 44, 165-169.

Zarkawi, M., Al-Merestani, M.R. \& Wardeh, M.F., 1999. Induction of synchronised oestrous in indigenous Damascus goats outside the breeding season. Small Rumin. Res. 33, 193-197. 